\title{
Some notes on a historical perspective of panic disorder
}

\author{
Algumas notas sobre uma perspectiva histórica do transtorno de pânico
}

Antonio Egidio Nardi

\begin{abstract}
This article aims to describe important points in the history of panic disorder concept, as well as to highlight the importance of its diagnosis for clinical and research developments. Panic disorder has been described in several literary reports and folklore. One of the oldest examples lies in Greek mythology - the god Pan, responsible for the term panic. The first half of the 19 th century witnessed the culmination of medical approach. During the second half of the 19th century came the psychological approach of anxiety. The 20th century associated panic disorder to hereditary, organic and psychological factors, dividing anxiety into simple and phobic anxious states. Therapeutic development was also observed in psychopharmacological and psychotherapeutic fields. Official classifications began to include panic disorder as a category since the third edition of the American Classification Manual (1980). Some biological theories dealing with etiology were widely discussed during the last decades of the 20th century. They were based on laboratory studies of physiological, cognitive and biochemical tests, as the false suffocation alarm theory and the fear network. Such theories were important in creating new diagnostic paradigms to modern psychiatry. That suggests the need to consider a wide range of historical variables to understand how particular features for panic disorder diagnosis have been developed and how treatment has emerged.

Key words: agoraphobia, anxiety disorder, panic attacks, phobic disorder.
\end{abstract}

\begin{abstract}
Resumo
O objetivo deste artigo é descrever alguns pontos importantes na história do desenvolvimento do conceito de transtorno de pânico e ressaltar a importância do diagnóstico para o progresso da pesquisa e da clínica. 0 transtorno de pânico foi descrito em vários textos literários e folclóricos. Talvez um dos exemplos mais antigos seja o deus Pan da mitologia grega, responsável pelo termo pânico. A primeira metade do século XIX presenciou 0 apogeu do processo de abordagem médica. Durante a segunda metade do século XIX iniciou-se a abordagem psicológica da ansiedade. No século $X X$, o transtorno de pânico foi associado a fatores hereditários, orgânicos e psicológicos, e a ansiedade, dividida em estados ansiosos simples e fóbicos. O desenvolvimento terapêutico foi também observado nos campos da psicofarmacologia e da psicoterapia. As classificações oficiais começaram a incluir uma categoria diagnóstica para transtorno de pânico, começando com a terceira edição do American Classification Manual (1980). Algumas teorias biológicas para a etiologia têm sido muito discutidas desde as últimas décadas do século XX, baseadas em estudos laboratoriais de fisiologia, com testes cognitivos e bioquímicos, como a teoria do alarme de falsa sufocação e o circuito central do medo. A importância das teorias na criação de novos paradigmas diagnósticos na psiquiatria moderna sugere a necessidade de considerar um amplo espectro das variáveis históricas para entender como o conceito do diagnóstico de transtorno de pânico foi desenvolvido e como as opções terapêuticas surgiram.

Palavras-chave: ataques de pânico, transtorno de ansiedade, transtorno fóbico, agorafobia.
\end{abstract}




\section{Introduction}

Although a common mental disorder (Weissman, Myers, 1980), panic disorder (APA, 2000) has received little historical attention and only recently has it come to be considered a disorder of its own. The history of panic disorder is interesting as how symptoms wax and wane in the history of medicine. Berrios (1996) pointed that this may be due to its relative newness, or to the fact that the historical model used to account for traditional mental disorders is inappropriate for new disorders. Our aim is to describe some important points in the history of the concept of panic disorder and highlight how important for clinical and research developments is the presence of this diagnosis in official classifications.

The word anxiety is derived from the Indo-Germanic root angh for narrowness or constriction. This root was the source for the Greek term anshein, meaning to strangulate, suffocate, oppress and correlated Latin terms, such as angustus, to express discomfort, angor, meaning oppression or lack of air, and angere, signifying constriction, suffering, panic (Berrios, 1996).

This article explores the history of the clinical concept that is now denominated panic disorder (APA, 2000) in its various definitions and nominations through the ages. It is focused on clinical description studies in the development of the notion of panic disorder. The importance of anxiety theories in the creation of new diagnostic paradigms in modern psychiatry suggests the need to take into account a wide range of historical variables to understand how treatment has emerged and how particular features for panic disorder diagnosis have been developed.

\section{Historical overview}

\section{Antiquity}

Early civilizations saw madness as supernaturally inflicted. Assyrians and Egyptians regarded many diseases as hurled from the heavens. Greek myths and epics similarly viewed madness as visitations from gods (Porter, 2002).

Panic disorder, an anxiety disorder, is not a problem of our time: several literary reports and folklore demonstrate symptoms similar to what we call panic disorder nowadays. Maybe one of the oldest examples lies in Greek mythology - the god Pan. He was responsible for anxiety and originated the term panic (Merivale, 1969). Although born in Arcadia, Pan roamed the Greek mountains and roads. He was the god of flocks and shepherds, and since he was half man and half goat, with horns and goat legs, his appearance was frightening. He was very active and full of energy, but also very irritable. He loved music and played a small reed pipe, Syrinx. In several stories, Pan is reported to cause fright, screams, fears, terror and suffering. Like other gods, Pan harassed nymphs who ran from him, maybe because of his mien or due to his always unexpected and sudden apparition (Merivale, 1969). Like other woodland gods, he was feared by those who had to go through the forest, because meeting one of these deities could provoke an overwhelming and irrational fear, for no reason at all, what was known as panic terrors or panic attacks. Fear of meeting Pan again and being startled once more made travelers stop journeying through roads and avoiding going to the market (in
Greek, agora), thus developing agoraphobia (fear of large open or public places) (Berrios, 1996).

In ancient Greece, Plato (c.428-c.348 BC) presents in Timaeus a case of anxiety associated to an old Egyptian concept of the vacant womb (Plato, 1997). Although this description is often associated to hysteria, the original text describes a woman with acute anxiety that is very similar to panic disorder. "The uterus is an animal desirous of procreating children. When it remains unfruitful long periods beyond puberty, gets discontented and angry, begins to wander throughout the body, closing the air passages, impeding breathing, bringing about painful distress, and causing a variety of associated diseases" (Plato, 1997). Plato not only associated panic disorder to women of reproductive age, but also states that pregnancy improves the symptoms (in some cases) and that respiratory symptoms (dyspnea, difficulty in breathing) are common symptoms. By exalting mind and valuing order and logic, Greek thinkers defined for future ages the problem of the irrational. In making man the measure of all things, they plucked madness from the heavens and humanized it. Greek medicine, with its routine binary thinking, singled out two main manifestations of mood and behavioral disturbance: mania and melancholia. The fullest early clinical descriptions of these were advanced by Aretaeus of Cappadocia (c.150-200 AD) in his On the Causes and Signs of Disease (Porter, 2002). For Aretaeus and for classical medicine in general, they were severe mental disturbances. Anguish and dejection were its essential elements, but also involved were powerful emotions springing from hallucinations and sensations of suspicion, mistrust, anxiety, and trepidation.

\section{Medieval period}

Medieval Islamic and Christian medicine honored and followed the medical traditions begun by Hippocrates and systematized by Galen, Aretaeus, and others, and accounts of madness advanced by medieval learned doctors essentially repeated them. In herbals and leechbooks produced by early medieval monks, simplified classical learning was intermingled with folk beliefs and magical remedies. Melancholia and mania dominated diagnoses. Among the medievals, Bartholomaeus Anglicus, who taught in 13th-century Paris, in the Aretaean manner included under melancholia such states as anxiety, hypochondriasis, depression and delusion (Porter, 2002).

\section{Renaissance}

During the medieval period and the Renaissance, what we today consider to be severe anxiety syndrome was associated to the signs and symptoms of depression. In the 17th century, an English doctor, Robert Burton (1621), described in his book on depression (The Essential Anatomy of Melancholy) an acute anxiety episode, which Burton (1621) considered to be a type of fear:

"This fear causes in man, as to be red, pale, tremble, sweat; it makes sudden cold and heat to come over all the body, palpitations of the heart, syncope, etc. It amazed many men that are to seek or show themselves in public assemblies...Many men are so amazed and astonished with fear, they know not where 
they are, what they do, and which is worst, it tortures them many days before with continual affrights and suspicious..."

Burton (1621) described several types of pathological anxiety in a style quite different from today's scientific texts: associating philosophy and beliefs of the time. He listed fear of death, fear of losing a loved one and paranoid anxiety. He described anxiety based on delirium, associated to depersonalization, hyperventilation, hypochondria and even agoraphobia, as well as several types of phobias: of speaking in public, acrophobia, claustrophobia, and anticipatory anxiety.

The Renaissance was not only a time of man's rediscovery of man through art; it was also a time marked by science's rise in prestige, and when alchemy received scientific criteria. Paracelsus (1493-1541) was one of the leaders in the new art to question the hegemony of Hippocrates' humors (Stone, 2002).

From the time of Hippocrates up to the 17th century, description and interpretation of signs and symptoms of anxiety were determined by the principle of body fluids described by Hippocrates in Corpus Hippocraticum or by reports in layman and religious literature (Berrios, 1996). Corpus Hippocraticum consisted of a series of 70 medical treatises dating from the 5 th century AD, attributed to Hippocrates and his disciples. Blood, yellow bile, black bile and phlegm would be the four cardinal humors or fluids, and would be associated to distinctive features of each individual, including diseases.

Medical description of panic disorder began prior to the 19th century, during a period when psychiatry was established itself as an independent branch of study. Berrios (1996) states that anxiety symptoms and syndromes were known to witch doctors or medics since immemorial time. However, each symptom was treated as a separate medical complaint, as if it were an isolated physical problem. Symptoms were considered for its face value and treated as symptoms associated to the disorder of an organ; for example, palpitation was associated as a disease of the heart. No mental disorder was considered when these complaints were presented. Because of its physical characteristics - tachycardia, precordial discomfort, nausea, sweating, paresthesia, etc. -, these anxiety manifestations were identified and described by clinical physicians and not by psychiatrists.

\section{9th century}

Maurice Krishaber (1836-1883), a Hungarian othorhinolaryngologist who practiced in Paris, described la névropathie cérébro-cardiaque in 1873 associating some symptoms - dizziness, tachycardia, and restlessness, among others - to one unique neurocirculatory disease. The term neurosis referred to nerves, an organic, somatic disturbance, with no association to a psychiatric disorder (Berrios, 1996; Costa Pereira, 1997) but it is considered the first description of paroxysmic anxiety in French literature.

In French psychiatry (Costa Pereira, 1997), panic disorder has been studied since the 19th century under the name of acute episodes of distress, and was part of the description for various nosological entities such as Benedict-Augustin Morel's emotional delirium (delire émotif); Henri Legrand Du Saulle's fear of spaces (peur des espaces), based on Karl Westphal's texts on agoraphobia; Doyen's morbid terrors (terreurs morbides); from Brissaud's paroxystic anxiety (anxiété paroxystique) to the fear in the army (peur dans les armées) described by Brousseau. In the beginning of the 19th century, the French doctor LandréBeauvais defined distress as a "certain discomfort, restlessness, excessive physical activity", and stated that the symptoms could be associated to severe or chronic diseases.

Benjamin Rush (1745-1813), an American physician from Philadelphia considered the father of American psychiatry, described in his psychiatry book (1812) the association between somatic causes and phobias, relating depression (tristimania) to hypochondriasis (Berrios, 1996; Costa Pereira, 1997). Before 1850 , the symptoms of anxiety were still associated with signs and symptoms of depression. In 1858, Littré and Robin defined distress as "a feeling of oppression or weight in the epigastrium, associated to a great deal of difficulty in breathing or excessive sadness, this being the most advanced degree of anxiety". They also described anxiety as a "problematic and agitated state, with difficulty in breathing and precordial pressure: restlessness, anxiety and distress are three stages of the same phenomenon, in order of seriousness" (Berrios, 1996).

In the second half of the 19th century a progressive change began to take place in the field of anxiety symptoms (Stone, 2002; Costa Pereira, 1997). Somatic causes, that up to that time were fully accepted, began do divide attention with possible psychological causes. In 1872, Karl Friedrich Otto Westphal (1833-1890) described agoraphobia, the fear of wide and open places. He cited three male patients who demonstrated fear in wide streets and open spaces and who, at times, were compelled to ask passersby for help. In 1878, Legrand Du Saulle published a paper on the fear of spaces (peur des espaces), broadening Westphal's original concept. Du Saulle stated that "although we can observe now and previously that these patients fear open places, they can feel fear of theaters, churches, high balconies in buildings or whenever they are found near wide windows, or buses, boats or bridges" (Berrios, 1996; Stone, 2002).

Still in the second half of the 19th century, definitions of states of anxiety and agoraphobia became more specified and detailed (Costa Pereira, 1997). Benedict Morel's (1809-1873) studies were very important during that period. According to Morel (1976), in 1857, the category emotional delirium combined the organism's physical and moral sensibility symptoms, which have no relation whatsoever with the signs and symptoms that are today considered psychotic. Morel listed as physical symptoms: hyperesthesia, paresthesia, hot and cold flashes, sweating, pain, etc. Phobias were among moral symptoms. The explanation given by Morel for this emotional delirium was recorded in his general theory of degeneration. Among Morel's cases we can observe what would today be described as panic disorder and generalized anxiety disorder. The physical and moral causes would be combined with hereditary factors, in order to appear as a disease, from the moment that determining conditions - moral and physical - were present. Base alteration would be the functional fragility of the visceral, ganglionary, and nervous system (Morel, 1976). Henry Maudsley (1835-1918), in 1879 in his book The Pathology of Mind, described a melancholic 
panic, and this was the first time the term panic was technically used in psychiatry (Berrios, 1996). It is important to highlight the notion that all the symptoms could be the manifestation of a unitary construct - anxiety - was new and had limited acceptance in 19th-century psychiatry.

At the end of the 19th century, two American doctors played a fundamental role in the future make up of Freud's proposed anxiety neurosis: George M. Beard and Jacob Mendes Da Costa (Berrios, 1996; Stone, 2002). The first studied neurasthenia, and was cited by Freud in his articles on anxiety neurosis. Beard's 1869 article entitled Neurasthenia was the starting point for a series of papers with the objective of establishing the specificity of neurasthenia, both in the clinical description and in the explanatory hypothesis. According to Beard, neurasthenia would be centered on physical fatigue of nervous origin (related to nerves, a neurological concept) - functional weakness of the brain due to sexual energy drain from abnormal sexual activity, such as excessive masturbation -, and would be accompanied by other symptoms such as pain, digestive problems, paresthesia, depression, reduced libido, apathy and indifference. But, what was most important, from the anxiety point of view, was that Beard's ample description of neurasthenia considered acute anxiety a very important part. The morbid fears of particular type, especially agoraphobia, anthropophobia (fear of society) and the phobia of traveling alone. Freud's criticism of Beard's work led Freud to introduce his own description for anxiety neurosis.

Jacob Da Costa (1833-1900), a military doctor, during the American Civil War described what he called the irritable heart, a functional cardiac disorder (Berrios, 1996; Stone, 2002). Men affected by this disorder demonstrated acute symptomalogy with palpitations of variable intensity, lasting from minutes to hours, accompanied by thoracic pain and general discomfort. Since he couldn't find an organic cardiac lesion or subjective conditions due to war, Da Costa concluded that this was a functional disorder of the sympathetic nervous system. When the heart is submitted to extremely intense effort and tension, it becomes physiologically irritable, and as a result palpitations arise.

Sigmund Freud (1856-1939) (1925) was also impressed by the symptoms and phobias associated with what we call today panic disorder. At around 1894, Freud (1925) described anxiety neurosis (Angstneurose). The origin of the term goes back to the studies by E. Hecker, who in 1893 had already demonstrated the presence of anxious states in neurasthenia. Freud's merit was to separate anxiety neurosis from neurasthenia and describe it with a specific clinical presentation. On several occasions, Freud states that certain acute symptoms, such as dizziness, cardiac activity disorders, sweating, tremors, shock, diarrhea and "pavor nocturnus, are special forms of anxiety attacks, which he now denominates anxiety equivalent". Freud (1925) stated that "...these patients' symptoms are not mentally determined or removable by analysis, but they must be regarded as direct toxic consequences of disturbed sexual chemical processes".

Since Freud's first papers on anxiety neurosis, the anxiety attack was considered one of two fundamental forms of clinical manifestation of distress, the other being a chronic state. Freud also associated agoraphobia to anxiety neurosis. To him, agoraphobia referred to an effort made by the patient with the intention of not being stricken by anxiety attacks in unfamiliar circumstances, when he was not sure he could get help. It is interesting to note that the relation between agoraphobia and panic attacks, widely studied nowadays, was also discussed by Freud in his texts on the neurosis of anxiety.

\section{0th century}

In the 20th century, although some concepts on psychological factors in anxiety had already been discussed, symptoms of anxiety were still largely associated to hereditary and biological factors. In 1903, Pierre Janet (1903) described psychasthenia, a case of anxiety with somatic and obsessive symptoms, associating these signs and symptoms to a breakdown of feelings and liberation of primitive behavior. Janet believed that the psychological performance of an individual could be divided into five levels. At the superior level would be the harmonious reality function, followed by habitual and automatic actions, then imagination functions, emotional visceral reactions and muscular movements. The term and its definition would encompass a series of mental disturbances, including anxiety. Anxiety and distress were manifestations of this breakdown, but not its main component. In 1926, in his book De l'Angoisse a l'Exstase, Janet (1923) cites the case of Madelaine, a 40-year-old patient with severe signs and symptoms of anxiety, with possible panic attacks associated with constitutional factors.

In 1907, Emil Kraepelin (1856-1926) (1899) describes the neurosis of terror (Schreckneurose), in which panic attacks are etiologically associated to the affective state. In the sixth edition of his classic Psychiatrie. Ein Lehrbuch für Studirende und Aerzte, in the chapter on compulsive insanity, Kraepelin associated agoraphobia to anxiety attacks with several somatic symptoms. He related that the improvement of symptoms does not mean a concurrent improvement of agoraphobia: this state could persist indefinitely.

Ernest Kretschmer introduced in his Medical Psychology the panic attack as "an outburst of attempted impulsive movements", trying to take the individual away from the source of danger or excitement as quickly as possible (Stone, 2002). Panic attacks appear in the Legrand Du Salle's fear of spaces, which he determined the fear of feeling fear.

To Adolf Meyer (1866-1950) (Brodsky, 2004), a psychiatrist who influenced the first American classification manuals - Diagnostic and Statistical Manual of Mental Disorders (DSM-I and DSM-II) - the individual is a psychobiological being and any pathological manifestation would be a form of reaction to particular characteristics of the environment. Psychosis and neurosis would be different parts of the same psychiatric spectrum of continuous gradation, going from one extreme to the other.

Henrique Roxo (1946) divided neurasthenia in two groups: psychasthenia and nervousness. Psychasthenia included obsessions, phobias and impulses. Nervousness represented an extraordinary state of anxiety, (the patient) revealing a feeling of indescribable discomfort, in which kinesthesia disturbances play a very important role. Although the anxiety attack is described within the symptoms of nervousness, Roxo (1946) associated to both neurasthenia groups symptoms that nowadays are 
considered to be those of depressive syndromes and chronic and acute anxiety syndromes. Etiology was an association of psychological, environmental and constitutional factors, and treatment consisted of varied experimental medications that supposedly would act specifically on each subtype.

The second half of the 20th century marked a revolution in the practice of psychiatry. Not only was psychiatric diagnosis revised and modified, seeking reliability, but treatment also received marked assistance from psychopharmaceuticals. In 1954, Mayer-Gross (1889-1961) associated anxiety reaction to hereditary, organic and psychological factors, dividing it in simple and phobic anxious states. The latter included agoraphobia with associated somatic symptoms. Martin Roth (1917-) in 1959 described in the Proceedings of the Royal Society of Medicine a recurring combination of symptoms involving anxiety attacks, phobic avoidance of crowds, and a feeling of depersonalization. Roth emphasized that patients were typically women in their late twenties (Berrios, 1996; Stone, 2002).

The 1950's brought about the discovery of monoaminoxidase inhibitors and tricyclic antidepressants. This is followed by the advent of the benzodiazepines. Thus, the road was paved for a more efficient panic treatment. In 1959, Donald Klein, a New York psychiatrist, observed that patients with depressive-anxiety symptoms responded favorably to imipramine, a triclyclic antidepressant. It is interesting to note that after a few weeks, Klein (1964) and his patients were disappointed by the effects of imipramine and were ready to quit the experiment when nurses pointed out that patients were less anxious. Nurses noticed that patients reduced their trips to the nursing station to complain about being sick or dying; that they were more independent, walking around the hospital by themselves. Klein (1964) concluded that imipramine was efficient in panic attacks, but not on chronic anxiety. He also associated agoraphobia as a consequence of panic attacks, in which patients did not fear bridges or closed environments, but feared the possibility of having a panic attack and an immediate way out or help would be difficult or impossible.

Klein (1964) could still distinguish three types of panic attacks: spontaneous, situational (associated with an agoraphobic situation) and those provoked by a constant phobic stimulus (animals, height, darkness, etc.). His posterior observations and descriptions influenced the third edition of the American Classification Manual (DSM-III) (APA, 1980), in which the term panic disorder appears for the first time in an official medical classification. In no time, panic disorder became the most studied psychiatric disorder from a diagnostic and therapeutic point of view.

The DSM-III (APA, 1980) divided anxiety neurosis, also named in this classification of anxiety disorders, into panic disorder (acute anxiety) and generalized anxiety disorder (chronic anxiety), creating operational criteria for each category diagnosed. It also divided phobic neurosis into simple phobia, social phobia and agoraphobia (with or without panic attack). The extensive diagnostic reorganization of DSM-III continued for seven years, resulting in the magazine edition - DSM-III-R (APA, 1987). In that edition, agoraphobia no longer appears as an isolated category, but as a consequence of panic disorder, and is now listed under the term: panic disorder with and without agoraphobia. The criteria for panic disorder were simplified and closer to clinical: for example, all that was needed was one panic attack with phobic repercussion during one month to establish a positive diagnosis. In other words, greater importance was given to the phobic consequences of the panic attack and not just the physical symptoms of the attack. The DSM-IV (APA, 1992) maintained practically the same definitions, but defined panic attacks demonstrating they could occur associated to other diagnosis and without fulfilling all the criteria for panic disorder; it also distinguished spontaneous panic attacks, situational panic attacks (linked to agoraphobia) and those provoked by a phobic stimulus (more closely linked to specific phobias). In the year 2000, a revised edition of DSM-IV was published, entitled DSM-IV-TR (APA, 2000), in which some of the concepts were refined but the criteria for panic disorder remained the same.

There was also another description of the panic disorder/agoraphobia connection. The prevailing view in American psychiatry, as reflected in the DSM-IV-TR, has been that agoraphobia is almost always a complication of panic disorder. An alternative view, more closely allied with European psychiatry and reflected in the tenth revision of the International Classification of Diseases (ICD-10) (WHO, 1992), is that agoraphobia is a distinct disorder that may or may not follow the onset of panic attacks (Marks, 1987). In ICD-10, the diagnosis of panic disorder with agoraphobia is given only if a primary diagnosis of agoraphobia has been excluded.

At least three central neurotransmitter systems noradrenergic, serotonergic, and gama-aminobutyric acid (GABA) - are acutely affected by certain pharmacological compounds that provide therapeutic benefit for patients with panic disorder (Gorman et al., 2000). The serotonergic system is a major area of focus for anxiety including panic disorder (Graeff, 1990). Serotonin has been implicated in the neurochemistry of anxiety for a long time. Drugs that block the reuptake of $5-\mathrm{HT}$ from the synaptic cleft back to the nerve terminal demonstrated efficacy across the board of different anxiety disorders (Graeff, 1991). The development of specific ligands allows the visualization and the study of the multiplicity of 5-HT receptors and their functional role in health and disease (Graeff, 1991). Evidence for an etiological role of serotonergic dysfunction in panic disorder remains sparse. Animal studies have indicated that fear and anxiety-like states are mediated by structures that include amygdala, hippocampus, prefrontal cortex, locus ceruleus, and periaqueductal gray (Graeff, 1990). Because of reciprocal connections between these structures, the amygdala with prominent prefrontal connections appears to integrate fear-related responses most effectively (Gorman et al., 2000).

Tone (2005) explored the history of psychiatry and the rise of biological psychiatry and suggests ways in which the study of history can shed light on current psychiatric practice. Focusing on anxiolytics as a case study in the development of psychopharmacology, she shows how social and political factors converged to popularize, and later stigmatize, outpatient treatments for anxiety. We can divide the evolution of psychopharmacology in relation to panic disorder into three main moments: first, Donald Klein's observation of the efficiency of the tricyclic antidepressants (Klein, 1964). The 
second moment was when the efficiency of the benzodiazepines versus alprazolam and clonazepam was perceived (Sheehan, 1982). Finally, in 1990, by the noted efficiency of the selective serotonin re-uptake inhibitor antidepressants (Boyer, 1995). Today, psychopharmacology has been leading psychiatry in the direction of biology. This biological perspective entails in putting anxiety in the frame of evolutionist paradigm. Charles Darwin (1872), in The Expression of Emotion in Man and in Animals, pointed the way to search for the adaptive value of the behavioral and psychological processes. Anxiety and fear have their roots in the defensive reactions of animals, observed in response to the danger normally found in the environment. The interpretation of a stimulus or a situation as dangerous depends on the nature of cognitive operations. In humans, cognitive factors acquire importance due to the intervention of the system of symbols socially codified, verbal or non-verbal. Behavioral responses to fear are accompanied by intense physiological alterations - physical symptoms - and alterations in the emotional state. Physiological alterations consist of objective measures of anxiety. Thus, cardiac frequency, arterial pressure, respiratory frequency and increased electrical conductivity of the skin brought on by sweating, are the measures mostly used to determine the degree of anxiety.

In their independent research, Jack Gorman, in the USA, and Van den Hout, in the Netherlands, in 1984, observed panic symptoms after inhalations of a $35 \%$ carbon dioxide mixture (Gorman et al., 2000). This observation afforded the opportunity for greater insight concerning the factors that brought about panic attacks. Donald Klein (1993) described the false suffocation alarm theory. That theory describes panic attack as a disorder of the physiological suffocation alarm. The regulating monitor would inform the central nervous system of an imminent suffocation situation when this was not actually occurring. This theory has been widely accepted, based on laboratory studies of respiratory, cognitive and biochemical tests.

\section{1st century}

Panic attacks seem to originate from a network of fear with altered sensibility. This network includes pre-frontal cortex, insula, thalamus, amygdala and amygdala projections toward the brain stem and hypothalamus (Gorman et al., 2000). If we administered a panicogenic agent, we would not affect a specific autonomic area of the brain stem, but we would be activating the entire neural fear net. Patients with panic disorder often complain of uncomfortable somatic sensations. The administration of a panicogenic agent would correspond to a non-specific activation.
Since all these agents produce uncomfortably sharp physical sensations, the hypothesis would be that they stimulate a sensitive brain system conditioned to responding to noxious stimuli. As time passes, the projections of the central nucleus of the amygdala such as the locus ceruleus, periaqueductal gray area, and hypothalamus can become more or less sensitive (Gorman et al., 2000). There can also be an interindividual difference in the strength of these afferent projections. In this way, the standard neuroendocrinal and autonomic responses presented during a panic attack may vary from one patient to another, and on the same patient throughout time.

The 21 st century will probably be marked by the development of genetic and neuroimaging data about panic and other anxiety disorders (Nardi, 2006). Panic attacks seem to originate from a network of fear with altered sensibility. This network includes pre-frontal cortex, insula, thalamus, amygdala and amygdala projections toward the brain stem and hypothalamus (Gorman et al., 2000). Recent research on physiological consequences during a panic attack has shown remarkable findings in regional brain activity in different neuroimaging studies (Gorman et al., 2000). The studies have shown significant increases of cerebral blood flow in panic disorder in several subcortical structures, including thalamus, hypothalamus, and periaqueductal gray region, in addition to the somatosensory and associative cortices, and the cingulate. Advances in the neuroimaging techniques and technologies available to study key areas involved in panic attacks, and the ability to induce laboratorial panic attacks, thus further detailing brain function during one, will greatly increase our understanding of the exact neuroanatomical substrates for panic and phobic avoidance. They will also further our understanding of the sites of action of effective therapies. The combination of neuroimaging techniques, laboratorial induction of panic attacks, and psychopharmacological or psychotherapeutic trials could allow a greater understanding of panic disorder, perhaps even new insights into the neuroanatomy and neurophysiology of anxiety disorders.

\section{Conclusion}

Panic disorder has a long history in the way man understands anxiety and its symptoms. In the last century panic disorder had its mysteries revealed through basic and clinical research, and patients who suffer from this frightening disease can be sure that diagnosis and efficacious treatment are already part of everyday clinical practices. We have, however, to perfect these practices even more, so we can continue to improve our knowledge about the disorder. 


\section{References}

American Psychiatric Association (APA). Diagnostic and Statistical Manual of Mental Disorders - DSM-III, Third Edition. Washington DC: American Psychiatric Press; 1980.

American Psychiatric Association (APA). Diagnostic and Statistic Manual of Mental Disorders - DSM-III-R. Third Edition-Revised. Washington, DC: American Psychiatric Press; 1987.

American Psychiatric Association (APA). Diagnostic and Statistical Manual of Mental Disorders - DSM-IV, Fourth Edition. Washington DC: American Psychiatric Press; 1994.

American Psychiatric Association (APA). Diagnostic and Statistical Manual of Mental Disorders - DSM-IV-TR, Fourth Edition - Text Revision. Washington DC: American Psychiatric Press; 2000.

Berrios GE. Anxiety and cognate disorders. In: Berrios GE. The History of Mental Symptoms. Descriptive psychopathology since the nineteenth century. University Press, p. 262-88, Cambridge, 1996

Boyer W. Serotonin uptake inhibitors are superior to imipramine and alprazolam in alleviating panic attacks: a meta-analysis. Int Clin Psychopharmacology,10: 45-9,1995.

Brodsky A. Benjamin Rush: Patriot and Physician. New York: St. Martin's Press; 2004.

Burton R. The Essential Anatomy of Melancholy [1621]. New York: Dover Publications; 2002.

Costa Pereira ME. Pânico: contribuição à psicopatologia dos ataques de pânico. São Paulo: Lemos Editorial; 1997.

Darwin C. The Expression of Emotion in Man and in Animals [1872] London: Fontana Press; 1999.

Freud S. Autoprésentation. In: Oeuvres Complètes [1925]. Vol. XVII. PUF, p.73-4, Paris, 1992.

Graeff FG. Brain defense systems and anxiety. In: Roth M, Burrows GD, Noyes R, editors. Handbook of Anxiety. vol. 3. Elsevier Science, p. 307-57, Amsterdam, 1990

Graeff FG. Neurotransmitters in the dorsal periaqueductal gray and animal models of panic anxiety. In: Briley M, File SE, editors. New Concepts in Anxiety. MacMillan Press, p. 288-312, London, 1991

Gorman JM, Kent JM, Sullivan GM, Coplan JD. Neuroanatomical hypothesis of panic disorder, revised. Am J Psychiatry, 157 493-505, 2000.
Janet P. Les obsessions et la psychasthénie [1903]. New York: Arno Press; 1976

Janet P. De l'angoisse à l'extase. Paris: Flammarion; 1923.

Klein DF. Delineation of two drug-responsive anxiety syndromes. Psychopharmacologia, 5: 397-408, 1964.

Klein DF. False suffocation alarms, spontaneous panics, and related conditions: an integrative hypothesis. Arch Gen Psychiatry, 50: 306-17, 1993

Krapelin E. Psychiatrie. Ein Lehrbuch für Studirende und Aerzte [1899]. Edition 6. New Delhi: Science History Publications; 1990.

Marks IM. Fears, Phobias, and Rituals: panic, anxiety, and their disorders. New York: Oxford University Press; 1987.

Mayer-Gross W. Clinical Psychiatry. London: Bailliére, Tindall \& Cassell; 1954.

Merivale P. Pan, the Goat-God. His Myth in Modern Times. Cambridge: Harvard University Press; 1969.

Morel BA. Traité des dégénérescences physiques, intellectuelles et morales de l' espèce humaine. [1857]. New York: Arno Press; 1976.

Nardi AE. Re: Listening to the past: history, psychiatry, and anxiety. Can J Psychiatry, 51: 61, 2006.

Plato. Complete Works. Cooper JM, editor. Hackett, p. 1224-91, Indianapolis, 1997.

Porter R. Madness. A Brief History. New York: Oxford University Press; 2002.

Roxo HB. Manual de Psiquiatria. Rio de Janeiro: Editora Guanabara; 1946.

Sheehan DV. Current perspectives in the treatment of panic and phobic disorders. Drug Therapy, 12: 179-93, 1982.

Stone MH. History of anxiety disorders. In: Stein DJ, Hollander E, organizers. Textbook of Anxiety Disorders. American Psychiatric Press, p. 3-11, Washington DC, 2002.

Tone A. Listening to the past: history, psychiatry, and anxiety. Can J Psychiatry, 50: 373-80, 2005.

Weissman MM, Myers JK. Psychiatric disorders in a US community: the application of Research Diagnostic Criteria to a resurveyed community sample. Acta Psychiatr Scand, 62: 99-111, 1980.

World Health Organization. The ICD-10 Classification of Mental and Behavioural Disorders: Clinical Description and Diagnostic Guidelines. Geneva: World Health Organization; 1992. 